UDK 159.9.72

\title{
CALL FOR CROSS-NATIONAL RESEARCH: HOW DO STUDENTS VIEW THEIR UNIVERSITY?
}

\author{
Anna Maria Voitko, Harold Takooshian \\ Fordham University \\ 113 W. 60th Street, New York, NY, USA, 10023
}

\begin{abstract}
How do students view their own university?" The answer to this important but elusive question offers a welcome opportunity for cross-national research. In this two-part report, part one reviews the value of 360-degree feedback for educational institutions - why and how this may promote cross-national research. Part two offers a case study of research at Fordham University, examining a shift in student attitudes after the opening in 2016 of a new half-billion dollar Law School building in New York City.
\end{abstract}

Key words: 360 -degree feedback, cross-national, satisfaction, higher education, law students, attitudes

"How do students view their own university?" The answer to this important but elusive question offers a welcome opportunity for cross-national research. This two-part report offers: (a) a call for cross-national research on this global question, followed by (b) a case study of this research at Fordham University, after it opened a half-billion dollar new Law School building in 2016.

\section{A call for research}

Around the world in 2017, an estimated 151 million students in 193 nations study at roughly 17,000 universities across Europe (4,000 universities), North America $(3,400)$, Latin America (1,300), India (1,600), China (1,200), Russia (1,000), Japan (800), Africa (600), Australia (100), and elsewhere ${ }^{1}$.

There is a natural tendency on many levels - governments, the schools themselves, and individual students - to want to compare these universities on some objective metrics. Since 2003, several "world university ranking" systems have emerged ${ }^{2,3}$, each with its own formula to compare major universities ${ }^{4}$. Though the various formulae carefully

1 Universities: http://www.webometrics.info/en/node/24

${ }^{2}$ Ranking history: https://en.wikipedia.org/wiki/College_and_university_rankings

3 Top rankings: https://www.topuniversities.com/university-rankings/world-universityrankings/2016

${ }^{4}$ Ranking method: https://www.topuniversities.com/qs-world-university-rankings/methodology 
combine diverse inputs, one input is typically absent: survey data on how students regard their own university, a vital part of "360-degree feedback" (Howard, 2016).

"In 360-degree feedback programs, performance ratings are gathered from supervisors, subordinates, peers, customers, and suppliers" (Riggio, 2008, p. 132). Since 360-degree feedback was first developed by I-O psychologists in the 1970s, it has become essential to the success of major corporations, including $90 \%$ of Fortune 500 firms $^{1}$. It is now standard practice for competitive corporations to have their employees complete an annual Employee Attitude Survey (EAS), to chart the performance of their organization across departments and years, playing "a vital role in its ability to provide structured, in-depth information" (Hosain, 2016, p. 21).

How ironic that 360 -degree feedback is so ubiquitous in corporate and other organizations, yet so absent in educational organizations. Though some schools allow student feedback on individual courses or faculty, how often do universities chart their progress by seeking anonymous, systematic, periodic feedback from their students? Like employees or clients of a corporation, students are ideally situated to offer valuable, detailed, insider information to a university interested to monitor and improve its own performance over time and departments (Symonds, 2014). Yet it is the rare university that makes an effort to seek periodic 360-degree feedback from its students to chart its own progress (Grafman \& Takooshian, 2011).

Cross-national research. Does this omission of students' views offer a welcome opportunity for psychology faculty and students to collaborate easily on cross-national research? Yes.

Back in the 1980s, one classic analysis of psychology research publications in the USA found that " $72 \%$... of articles used North American undergraduates as subjects" (Sears, 1987, p. 526). In 2012, a 25-year follow-up analysis found that still only $4.8 \%$ of research journal articles were based on cross-national samples (Li, Kim, Karp, \& Takooshian, 2012). In recent years, psychologists world-wide have increasingly recognized the value of collaborative cross-national research, to compare human attitudes and behaviors across national boundaries (Takooshian \& Stevens, 2001). Past obstacles to cross-national research (language, distance, cost, culture) are now being reduced by new technologies the Internet, survey and statistical software. For cross-cultural psychologists, the ideal cross-national survey is a one-page sheet containing brief items using simple words that can be translated easily (Takooshian, Mrinal \& Mrinal, 2001). Some simple cross-national surveys on diverse topics appear on-line ${ }^{2}$, and have been used to teach psychometrics and research methods to students in different nations.

A cross-national 360-degree student survey is especially attractive for several reasons. Compared with the often diverse goals of global corporations that use 360-degree feedback, universities across nations share the same simple core mission, to educate students. We can ask the same universal questions about a school's faculty (their expertise, availability), students (their diversity, ability), services (library, computers), and other features (cost, leadership).

\footnotetext{
1 360-degree feedback: https://en.wikipedia.org/wiki/360-degree_feedback

2 Cross-national surveys: http://file-id.org/130614/1027
} 
For example, consider Peoples' Friendship University of Russia (RUDN University) in Moscow. Launched as a multicultural institution by Russian authorities in 1960 - with 288 students from 47 nations - RUDN University has grown steadily in 57 years to include today 21,928 students from 152 nations ${ }^{1}$. RUDN University is among the "top 500" world universities ${ }^{2}$ and, in 2013, was the first university in mainland Europe to form a chapter of Psi Chi, the International Honor Society for Psychology (McCormick et al., 2014). Since 2003, it publishes the RUDN Journal of Psychology and Pedagogics - a bilingual refereed journal with research reports from different nations ${ }^{3}$. RUDN University has a global reputation for its cross-cultural research with its students, where the RUDN "Center for Personality Studies" uses psychometric methods to study cross-cultural adaptation of its students (Novikova, 2013, p. 64).

Like 360-degree surveys in corporations, an anonymous, standardized student survey could achieve many goals within RUDN to: (a) compare one university over time; (b) compare RUDN with other universities inside or outside Russia; (c) compare different campuses, departments, programs, or other units within the same university; (d) relate RUDN students' views with their biodata: nationality, gender, age, specialty, years in school, campus resident/commuter, and more. Of course, such data is of value not only to students learning research methods, but also to university policy-makers who are charged with deciding the future of their university. Researchers may well ask policymakers to pose specific questions that can be addressed by the anonymous 360-degree student surveys.

One model cross-national survey (Formozova \& Urmanche, 2014) compared 1,048 students at two universities using a $2 \times 2$ design, and found that international students were significantly more satisfied (mean $=54.1$ out of 80 ) than domestic students (53.2) in a U.S. school, but significantly less satisfied (49.8) than domestic students (53.4) in a Russian school. In another report, Professor Jennifer Symonds (2014) of the University of Cambridge has suggested many more possibilities for such "student perception" surveys.

Part two of this report below is a detailed sample using this survey to compare attitudes within Fordham University.

\section{Research: How do law students regard their university?}

Starting in 2009, Fordham University researchers developed a 360-degree Student Survey, which could be easily adapted to any school. In this is one-page, 36-item questionnaire, students can express anonymously their views on their school (Bartel, 2009). The survey's 20 scale items had five items each on school (a) facilities, (b) professors, (c) students, and (d) other features. The 20 items were each scored $0-4$, so the 4 scales varied from $0-20$, and the total from $0-80$. The remaining 16 items recorded students' biodata. (See Appendix).

${ }^{1}$ RUDN history: https://www.youtube.com/watch? $v=$ cAZYUL-xPjI\&index=3\&list=PLgvejCw 5U1S8kh9RH113VJJQmA926D2Pz

${ }^{2}$ RUDN ranking: https://www.topuniversities.com/node/9969/ranking-details/world-universityrankings/2013

3 RUDN journal: http://journals.rudn.ru/psychology-pedagogics 
Law School. Since 2009, many students have chosen this survey for their research courses, to test diverse hypotheses about students' views of their university, while amassing a database of over 1,000 Fordham students' surveys. One of these reports focused on Fordham Law School. Haller (2013) confirmed her hypothesis that Fordham Law students scored significantly higher across 14 of 20 items, averaging (57.15) compared with students in the university's other nine schools (53.27). But Fordham University and its Law School have changed greatly since 2013 , in a few ways

Building. In 2014, Fordham unveiled its newest addition to the Lincoln Center campus ${ }^{1}$. The palatial 22-story, 468,000 square-foot building served the dual purpose of hosting Fordham's School of Law and housing undergraduate freshman students. The 339,000 -square-foot portion dedicated to the School of Law "features 26 classrooms, lecture halls, seminar and conference rooms, a two-story atrium, a trial court facility, and a 90,000-volume law library" (Kestenband, 2016, p. 1). Despite exceeding its 250 million dollar budget, the building is a cost-efficient solution to the university's expansion needs in a notoriously expensive real estate location. The visual aesthetics and the detail that went into its construction cannot be overlooked. The building was designated LEED Silver by the U.S. Green Building Council (Kestenband, 2016). It was also one of the recipients of the 2016 International Architecture Award by the Chicago Athenaeum: Museum of Architecture and Design and the European Centre for Architecture Art Design and Urban Studies (Newsroom, 2016).

Food service. Other, more subtle changes have also occurred since 2013. Starting on July 1, 2016, Fordham University as a whole also switched food providers from Sodexo to Aramark (Kozub, 2016), after suffering years of poor food reviews, ranked as the worst campus food by the Princeton Review in 2012. This ranking moved up to number 5 from the bottom in 2013 (Ryan, 2013). At the time of the present study, Aramark had been servicing the university for almost a year. Altogether these changes represent the University's continued investment in its students, albeit at the expense of increasing tuition.

Tuition. As Fordham Law continues to raise its tuition every year the financial gap between it and comparable schools grows larger. At the time of Haller's (2013) study Fordham Law was ranked in the top 20 most expensive law schools in the U.S. and charged full-time students $\$ 50,996$. In 2017 U.S. News report ranked Fordham's Law school as 36th in the country, tied with University of Colorado-Boulder. Fordham's tuition for a full time student was $\$ 56,146$ which is higher than 20 of the schools ranked $1-35$ on the list and over $\$ 20,000$ more than University of Colorado - Boulder (Best Law Schools, 2017). However, Fordham Law also ranked 15 among law schools for the highest average graduate salary (Newsroom, 2017). Whether or not this silver lining is enough to mitigate student tuition concerns is unclear.

Regulations. Additionally, two regulation proposed by the American Bar Association (ABA) increased the need for continuous 360 degree feedback. To combat the nationwide decrease in bar passage rates, the first proposal would require accredited law schools to maintain a student bar-passage rate of $75 \%$ and to include as many student cases as possible in their annual reports. The second proposal would jeopardize the accreditation of a law school that loses $20 \%$ of its' first year students to non-transfer attrition. This

${ }^{1}$ Fordham Law building: https://artsbeat.blogs.nytimes.com/2014/09/23/new-fordham-buildingopens-at-lincoln-center/ 
proposal was made under the assumption that schools with high rates of attrition are admitting students who are under-qualified for the program (Hansen, 2016). As of 2016 Fordham's School of Law met both the bar-passage and low attrition requirement. The majority of attrition was due to academic transfers (Standard 509 information report, 2016). However, consistent use of 360- degree feedback could provide insight into why these transfers occur and alert the school to other student trends.

Hypotheses. The present study updated Fordham Law students' views, with two hypotheses: (1) Fordham Law students are more satisfied with their new school than other Fordham students. This was based on the higher satisfaction found by Haller (2013). (2) Like other students, Law students attitudes correlated with their biodata.

\section{Method}

Participants were 30 Fordham University Law students in May of 2017, 57\% women, $89 \%$ day students, $7 \%$ living on campus, $10 \%$ Catholic, $100 \%$ full-time students, $23 \%$ employed during school, mean age between 20 to 29 years $(S D=2.5)$, mean number of years at Fordham was $1.83(S D=.85)$.

These 30 Law students were compared with 1,527 other Fordham students who had previously completed the Fordham 360-degree feedback survey. These 1,527 were $61 \%$ women, $62 \%$ day students, $35 \%$ living on campus, $28 \%$ Catholic, $88 \%$ full-time students, $69 \%$ employed during school, mean age between 20 to 29 years $(S D=2.5)$, mean number of years at Fordham was $1.96(S D=.85)$.

Materials. The 36-item Student Survey was a modified version of the original Fordham 360-degree feedback Student Survey developed by Bartel (2009), see Appendix. The Student Survey was in three parts: (a) a brief introduction, (b) a 20-item scale, with four 5-item subscales (facilities, professors, students, other), and (c) 16 biodata items and qualitative questions. The 20 items were scored 0 (low) to 4 (high), so the four 5-item scales vary from $0-20$, and the total scale from $0-80$.

The reliability of the five scales was assessed by Cronbach's alpha, and proved moderate to high for these brief five-item scales: Facilities $\alpha=.64$, Professors $\alpha=.80$, Students $\alpha=.70$, Other $\alpha=.57$, Total $\alpha=.84$.

Procedure. Fordham Law students were approached either between classes or in their cafeteria and asked to complete a short survey on their attitudes towards Fordham. The Student Survey took approximately 10 minutes to complete, and about $50 \%$ of students agreed. Their responses were collected and coded in SPSS.

An independent-sample t-test compared the 30 law students with 1,527 other students who previously completed the survey. These results were later compared with Haller (2013). A Pearson correlation also compared the total attitude scores (0-80) with select biodata: age, gender, attendance, number of years at Fordham, employment status, and day/evening schedule.

\section{Results}

Our primary hypothesis was strongly confirmed, that Fordham Law students were more satisfied with their experiences than other Fordham students (see Table 1). Based on independent sample t-tests, Law students scored significantly higher on 16 of 20 items, 
and all five scales, and significantly lower on only 1 of 20 items (\#12, "I like the diversity among students"). Compared with a mean Total score for Law students of 57.15 found by Haller in 2013, the present student found a lower mean of 53.59 for all students, and far higher 62.69 for 30 Law students.

Comparison of mean attitudes of Law with other Fordham students

\begin{tabular}{|c|c|c|c|}
\hline$N=1527$ & $N=30$ & \multirow{2}{*}{ Differ?** } & \multirow{2}{*}{ Scales and items } \\
\hline Overall & Law & & \\
\hline \multicolumn{4}{|c|}{ "Overall, I am satisfied with Fordham..." } \\
\hline 1.72 & 2.10 & & cafeteria \\
\hline 2.73 & 3.37 & ++ & library \\
\hline 2.11 & 2.80 & ++ & student services \\
\hline 2.83 & 3.27 & + & campus security staff \\
\hline 2.64 & 3.07 & + & computer facilities \\
\hline 12.03 & 14.61 & ++ & FACILITIES (range $=0$ to 20$)(\alpha=.644)$ \\
\hline \multicolumn{4}{|r|}{ "Most professors at Fordham..." } \\
\hline 3.20 & 3.70 & ++ & are interested in their students' education \\
\hline 2.96 & 3.33 & + & present course material in a stimulating way. \\
\hline 3.27 & 3.77 & ++ & are an expert in their subject. \\
\hline 3.05 & 3.60 & ++ & have high morale. \\
\hline 3.09 & 3.57 & ++ & are available to students outside the classroom. \\
\hline 15.57 & 17.97 & + & PROFESSORS (range $=0$ to 20$)(\alpha=.794)$ \\
\hline \multicolumn{4}{|r|}{ "About Fordham students..." } \\
\hline 2.99 & 3.57 & ++ & They are hard-working. \\
\hline 2.83 & 2.70 & -- & I like the diversity among them. \\
\hline 2.21 & 2.20 & & There is a sense of "college life" among students on campus. \\
\hline 2.97 & 3.37 & + & They are friendly. \\
\hline 2.81 & 3.37 & ++ & They are well-prepared for college work. \\
\hline 13.81 & 15.21 & ++ & STUDENTS (range $=0$ to 20$)(\alpha=.716)$ \\
\hline \multicolumn{4}{|r|}{ Other } \\
\hline 2.51 & 3.07 & ++ & The student organizations add much to activities on campus. \\
\hline 2.15 & 2.73 & ++ & Academically, Fordham is comparable to an Ivy League school. \\
\hline 2.58 & 2.83 & & Deans seem available and helpful to students. \\
\hline 3.37 & 3.80 & ++ & The location of this campus is very good. \\
\hline 1.57 & 2.47 & ++ & Fordham tuition and fees are reasonable next to other schools. \\
\hline 12.18 & 14.9 & ++ & OTHER (range $=0$ to 20$)(\alpha=.559)$ \\
\hline 53.59 & 62.69 & ++ & TOTAL (range $=0$ to 80$)(\alpha=.845)$ \\
\hline \multicolumn{4}{|c|}{ 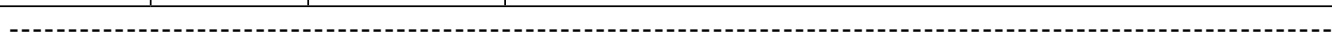 } \\
\hline 0.69 & 0.23 & -- & Employment $(0=$ no, 1 = part-time, 2 = full-time $)$ \\
\hline 1.96 & 1.83 & & Years at Fordham \\
\hline 1.88 & 2.00 & ++ & Attendance $(1=$ part-time, 2 = full-time \\
\hline 0.28 & 0.10 & - & Catholic $(0=$ no, $1=$ yes \\
\hline 0.35 & 0.07 & -- & Live in Fordham dorms $(0=$ no, $1=$ Lincoln Center, $2=$ Rose Hill \\
\hline 1.38 & 1.11 & -- & Primary class time (1 = Day, 2 = Evening) \\
\hline 1.95 & 2.07 & & Age (in decades) \\
\hline 1.61 & 1.57 & & Gender $(1=$ male, 2 = female $)$ \\
\hline
\end{tabular}

${ }^{\star *}$ Difference: Law students' mean is significantly higher/lower at $p<.05(+/-)$ or $p<.01(++/--)$. 
An independent sample t-test found that the present sample of Fordham Law students were significantly more satisfied with their facilities, professors, students and other aspects of their school. On an item by item basis, Fordham Law students had a significantly higher mean for 16 out of the 20 items. Additionally, the total score for Fordham Law students $(M=62.69, S D=6.75)$ was significantly higher than the total score for the other students, $(M=53.59, S D=9.9), t(1525)=4.98, p<.01$.

The second hypothesis was partially confirmed, that students' attitudes varied based on their biodata (Table 2).

Table 2

Pearson Correlation of biodata with 5 attitudes scales, comparing 1527 non-law students with 30 law students (in italic bold)

\begin{tabular}{|l|c|c|c|c|c|}
\hline & Facilities & Professors & Students & Other & Total \\
\hline \multirow{2}{*}{ Employed (0-2) } & $.05^{\star}$ & .01 & .02 & .02 & .04 \\
\cline { 2 - 6 } & -.01 & -.33 & -.16 & -.16 & -.22 \\
\hline \multirow{2}{*}{ Evening (1-2) } & $-.12^{\star}$ & $.08^{\star}$ & $.08^{\star}$ & $.06^{\star}$ & $.11^{\star}$ \\
\cline { 2 - 6 } & -.18 & .19 & .34 & $.53^{*}$ & .34 \\
\hline \multirow{2}{*}{ Years at Fordham } & $-.12^{\star}$ & $-.07^{\star}$ & $-.10^{\star}$ & .03 & $-.11^{*}$ \\
\cline { 2 - 6 } & .09 & .23 & -.05 & .08 & .11 \\
\hline \multirow{2}{*}{ Age } & .02 & $.05^{\star}$ & .04 & .01 & -.04 \\
\cline { 2 - 6 } Gender (1-2) & -.13 & .01 & -.02 & .11 & -.01 \\
\cline { 2 - 6 } & -.07 & .02 & .01 & .00 & .13 \\
\hline
\end{tabular}

Notes:

${ }^{*} p<.05$

Employed during the school year: $0=$ no, $1=$ part-time, $2=$ full-time

Evening (primary class time): Day $=1$, Evening $=2$

Gender: $1=$ male, 2 = female

In Table 2, with minor exceptions, we see a generally similar pattern when comparing Law with other students. The total score of 30 Law students correlated $r=+.11$ with their number of years at Fordham $(r=+.11, p=.62)$, compared with a significant correlation $(r=-.111, p<.01)$ for other Fordham students - indicating that non-law students are significantly less satisfied with Fordham the longer they attend it.

Our secondary hypothesis was that Fordham Law students sampled in 2017 would be more satisfied with their facilities than the sample taken by Haller in 2013. This hypothesis was also supported. The average score for facilities among law students in 2017 was 14.61 , nearly 3 points higher than the 11.88 score for facilities in 2014 .

\section{Discussion}

Strengths and Limitations. While both hypotheses were supported, the study had some limitations. The primarily limitation was the small sample size of Law students surveyed in 2017. While significant differences were found between this sample and other Fordham students, it is possible that the sample was not large enough to adequately represent all Fordham Law students. However, the study also had several strengths. First, the comparison group had over 1500 students increased the chance that scores for the comparison group were representative of the Fordham population as a whole. Additionally, while the present 
sample of Law Students was small, the results were consistent with Haller's (2013) previous study. Finally, the study was conducted directly after major changes at Fordham University which made the feedback especially valuable.

Significance. The study's findings are significant in a few ways. First, the much higher mean of 62.69 for law students indicates that the enormous amount of money Fordham spent in constructing the new law building has led to a tangible increase in student satisfaction. As Fordham has a history of financial struggles and even now is battling with health coverage for its faculty, studies like this one provide valuable input on resource allocation. By consistently measuring student satisfaction after new additions to the campus, Fordham can gauge which projects have the biggest impact on its students.

Second, this study adds to the small but growing line of research using 360-degree feedback in higher education. As universities continue to grow and play a larger role in the lives of current and future generations it is essential to implement feedback systems that go beyond teacher and course evaluations. For students, 360-degree feedback allows them to express concerns over portions of academic life that were traditionally overlooked. For the university, the feedback is a rich source of self-improvement. By formally surveying their students, universities across the world can clearly gauge the strengths and weaknesses of their institutions.

Future Research. There is much potential for future use of 360-degree feedback at universities, especially at schools with diverse populations or that are spread across multiple campuses. Many institutions could effectively utilize the feedback to see how satisfied different parts of the student body are with their school. Even a relatively small university such as Fordham had significant differences between it's law and non-law students.

Larger universities, or ones that have campuses spread across the world could take this a step further. A university that has several campus locations for example, could utilize 360 -feedback at each location to better understand the students they serve. It would also be of interest to see how the overall mission and policy of the school translates to campuses in various locations.

\section{REFERENCES}

American Bar Association. (2016). Fordham University School of Law - 2016 Standard 509 information report.

Bartel, C. (2009). How good is your school: Validation of a student life survey. Presentation at the 37th Hunter College Psychology Convention, NY, NY.

Best Law Schools. (2017). Retrieved from: https://www.usnews.com/best-graduate-schools/top- lawschools/law-rankings/page +2

Formozova, A., \& Urmanche, A. (2014). Using 360-degree feedback to compare Russian and American university students. International Psychology Bulletin. 18(2), 60-64.

Grafman, D., \& Takooshian, H. (2010). Seeking 360-degree feedback from university students: Why and how? Presentation to the 38th Hunter College Psychology Convention, New York City.

Haller, A. (2013). Law school students' view of their educational experience at Fordham. Presentation to the 41st Hunter College Psychology Convention, NY, NY.

Hansen, M. (2016). Proposals to amend law school accreditation standards would require more focus on grads' bar passage. ABA Journal. P. 22. 
Hosain, M.S. (2016). 360 Degree Feedback as a Technique of Performance Appraisal: Does it Really Work? Asian Business Review, 6(1), 21-24.

Howard, C. (2016). Top College Rankings 2016: The Full Methodology. Forbes. Retrieved from: https:// www.forbes.com/sites/carolinehoward/2016/07/06/top-colleges-ranking-2016-the-fullmethodology/\#3ffd9c8b5b82

Kestenband, R. (2016). Structural engineering at the intersection of two curves. Civil-Structural Engineer.

Kozub, S. (2016). Fordham drops Sodexo for Aramark food service provider. The Observer. Retrieved from: http://www.fordhamobserver.com/breaking-fordham-drops-sodexo-for-aramark/

Li, J., Kim, C.Y., Karp, S.R., \& Takooshian, H. (2012, Fall). A data-based profile of U.S. social psychology journals: 25 years later. International Psychology Bulletin, 16(4), 23-29.

McCormick, M.A., Takooshian, H., Denmark, F.L., del Pilar Grazioso, M., Velayo, R.S., Wang, A.Y., \& Zlokovich, M.S. (2014). Building bridges: Psi Chi and international psychology. RUDN Journal of Psychology and Pedagogics, (4), 5-16.

Newsroom. (2016). Fordham Law building recognized with international architecture award. Fordham Law News. Retrieved from: https://news.law.fordham.edu/blog/2016/07/19/fordham-lawbuilding-recognized-with-international-architecture-award/

Newsroom. (2017). Fordham Law ranked top 20 school for highest average salary. Fordham Law News. Retrieved from: http://news.law.fordham.edu/blog/2017/01/27/fordham-law-ranked-top-20school-for-highest-average-salary/

Novikova, I.A. (2013, Summer). Tolerance types of international students. International Psychology Bulletin, 17(3), 64-65.

Riggio, R.E. (2008). Introduction to Industrial-Organizational Psychology (6 ed.). Upper Saddle River NJ: Prentice Hall.

Ryan, C. (2013). Most students label on-campus food favorable, survey finds. The Fordham Ram. Retrieved from: https://fordhamram.com/2013/09/11/most-students-label-on-campus-foodfavorable-survey-finds-2/

Sears, D.O. (1986). College sophomores in the laboratory: Influences of a narrow data base on social psychology's view of human nature. Journal of Personality and Social Psychology, 51, 515-530.

Symonds, J.E. (2012, Summer). The international measurement of school perceptions: School environment, school climate, and student attitudes. International Psychology Bulletin, 18(2), $72-$ 74.

Takooshian, H., Mrinal, N.R., \& Mrinal, U.M. (2001). Research methods for studies in the field. In L.L. Adler \& U.P. Gielen (Eds.), Cross-cultural topics in psychology (2 ed.). (pp. 29-46). Westport CT: Praeger.

Takooshian, H., \& Stevens, M.J. (2001, Fall). Collaborating on cross-national research: Why and how. International Psychology Reporter, 5(3/4), 13-15. doi: 10.22363/2313-1683-2017-14-4: 10.1037/ e550012009-011 


\section{Fordham Survey}

Please take a moment to give us your frank views about Fordham. Circle each item below, either: (A) Agree strongly, (a) agree, (?) have no opinion, (d) disagree, (D) Disagree strongly.

This survey is anonymous. THANK YOU! **

Overall, I am satisfied with the Fordham:

1. A a ? D cafeteria.

2. A a ? D library.

3. A a ? d D student services (bursar, registrar, financial aid...).

4. A a ? d campus security staff.

5. A a ? D computer facilities.

Most of my professors at Fordham:

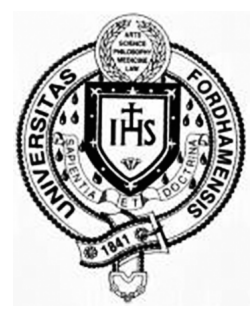

6. A a ? d D are interested in their students' education.

7. A a ? d D present course material in a stimulating way.

8. A a ? d D are expert in their subject.

9. A a ? d D have high morale.

10. A a ? d D are available to students outside the classroom.

About Fordham students:

11. A a ? D They are hard-working.

12. A a ? d D I like the diversity among them.

13. A a ? $\mathrm{d} D$ There is a sense of "college life" among students on campus.

14. A a ? D They are friendly.

15. A a ? d They are well-prepared for college work.

16. A a ? d D The student organizations add much to activities on campus.

17. A a ? d D Academically, Fordham is comparable to an Ivy League school.

18. A a ? d D Deans seem available and helpful to students.

19. A a ? d D The location of this campus is very good.

20. A a ? d D Fordham tuition and fees are reasonable next to other schools.

Now please describe yourself:

21. Age: $\square$ under $20 \square 20-29 \square 30-39 \square 40-49 \square 50-59 \square 60+$

22. Gender: $\square$ Male $\square$ Female.

23. Employed during school year: $\square$ No. $\square$ Yes, part-time. $\square$ Yes, full-time.

24. I attend Fordham: $\square$ Part-time. $\square$ Full-time.

25. My school is (circle:) (undergraduate) FCRH FCLC PCS CBA (post-graduate) LAW GBA GED GSS GRRE GSAS

26. The number of years have I studied at Fordham $=$ years.

27. (Optional:) My religion:

28. I live in Fordham dorms: $\square$ No. $\square$ at LC. $\square$ at RH. 


$$
\text { If so, I have lived _ years in its dorms. }
$$

29. I am an international student: $\square$ No. $\square$ Yes, nation:

30. I am a veteran studying on the current G.I. Bill: $\square$ No $\square$ Yes

If a veteran: I'd say Fordham is a "veteran friendly" school (circle one:)

Not at all 0123456789 very much

31. Campus? I study primarily at:

$\square$ LC-Manhattan $\square$ RH-Bronx $\square$ FW-Westchester

32. Time? I now study primarily in the: $\square$ Day $\square$ Evening

33. (Optional:) The thing I like most about Fordham is: [more space on back]

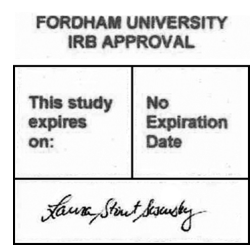

34. (Optional:) The thing I dislike most about Fordham is: [more space on back]

35. (Optional:) I offer this suggestion to improve Fordham: [space on back]

36. (Optional:) Any other comments on Fordham or this survey. [space on back]

** For any questions on this survey, or a free summary of the findings, contact Prof. Harold Takooshian at 212-636-6393ortakoosh@aol.com.For any general comments, contactirb@ fordham.edu.

(C) Voitko, A.M., \& Takooshian, H., 2017

\section{Article history:}

Received 18 July 2017

Revised 26 August 2017

Accepted 14 September 2017

\section{For citation:}

Voitko, A.M., \& Takooshian, H. (2017). Call for cross-national research: How do students view their university? RUDNJournal of Psychology and Pedagogics, 14 (4), 371-382. doi: 10.22363/23131683-2017-14-4-371-382

\section{Bio Note:}

Anna Maria Voitko - BS in Psychology, a Psi Chi Honor Student at Fordham University in 2017, a peer-reviewer for the Fordham Undergraduate Research Journal, and on the leadership committee for Fordham University Emerging Leaders (New York, USA). E-mail: avoitko@fordham.edu

Harold Takooshian - Ph.D. in Psychology, Professor of Psychology and Organizational Leadership at Fordham University (New York, USA). E-mail: takoosh@aol.com 


\title{
КАК СТУДЕНТЫ ВОСПРИНИМАЮТ СВОЙ УНИВЕРСИТЕТ: ВОЗМОЖНОСТИ ДЛЯ КРОСС-НАЦИОНАЛЬНЫХ ИССЛЕДОВАНИЙ
}

\author{
А.М. Войтко, Г. Такушьян \\ Университет Фордхэм \\ 60-я ул., 113, Нью-Йорк, штат Нью-Йорк, 10023, США
}

\begin{abstract}
«Как студенты воспринимают и оценивают свой собственный университет?». Поиск ответа на этот важный, но неоднозначный вопрос дает прекрасную возможность для кросснациональных исследований. В первой части данной статьи рассматриваются преимущества использования процедуры «360 градусов» для оценки образовательных учреждений: почему и как это может способствовать проведению кросс-национальных исследований. Во второй части представлено описание исследования, проведенного в Университете Фордхем, с целью выявить изменения в отношениях студентов-юристов к своему университету после открытия в 2016 г. нового здания юридического факультета в центре Нью-Йорка стоимостью полмиллиарда долларов.
\end{abstract}

Ключевые слова: процедура оценки «360 градусов», кросс-национальные исследования, удовлетворенность, высшее образование, университет, студенты-юристы, социальные установки

(C) Войтко А.М., Такушьян Г., 2017

\section{История статьи:}

Поступила в редакцию: 18 июля 2017

Принята к печати: 14 сентября 2017

Для цитирования:

Войтко А.М., Такушьян Г. Как студенты воспринимают свой университет: Возможности для кросс-национальных исследований // Вестник Российского университета дружбы народов. Серия: Психология и педагогика. 2017. Т. 14. № 4. С. 371-382. doi: 10.22363/2313-16832017-14-4-371-382

Сведения об авторах:

Войтко Анна Мария - бакалавр психологии, лучший студент Психологического общества почета Psi Chi 2017 года в Университете Фордхэм (Нью-Йорк, США). E-mail: avoitko@ fordham.edu

Такушьян Гарольд - Ph.D, профессор психологии и организационного лидерства в Университете Фордхэм (Нью-Йорк, США). E-mail: takoosh@aol.com 